\title{
Chemistry and the World of Today
}

\author{
Linus Pauling, California Institute of Technology, Pasadena, Calif.
}

\begin{abstract}
Support of a scientific research foundation by the nation's industrial corporations offers insurance that the corporations will have new products to manufacture in the future . . . Such a project could be maintained by investing only $0.375 \%$ of profits
\end{abstract}

W iatry and the World of Today"? My answer to this question is that I can say anything, discuss any feature of modern life, because every aspect of the world today-even politics and international relations--is affected by chemistry.

I do not need to point out to the members of the American Chemical Socrety the great contributions that are made by our chemical industries to the modern world. Everyone hats experienced in his daily life the effects of the discovery and development of a new fiber, nylon. We all have seen the revolution that has taken place in medical treatment through the discovery and extensive use of penicillin and other powerful antibiotics. During the past decade the world has been changed in a very significant way by the atomic bomb, which was constructed through the joint efforts of physicists, chemists. and enyincers.

Only recently, during the war years. when we began using up in practical applications our backlog of new basic discoveries, did it become clear to me that, although all scientists make their contributions to scientific progiess, modern life is really based on fundamental science, on pure rescarch, and that the nature of the world today has been determined, and the nuture of the world of the future will be determined, by the work, and especially the ideas, the imagination, of a small number of peoplethe "impractical scientists," mainly university professors, who strive to add to our body of knowledge in every way, rather than to solve certain practical problems that obviously need solution. I am not minimizing the importance of developmental research and of industrial spplication of new discoveries; but am instead pointing out that the direction in which progress occurs is in fact determined by the basic discoveries that are made, and that accordingly it is the progress of pure science that determines what the nature of the world will be a generation later.

It is clear that the synthesis of nylon resulted from the early researches on the structure of natural fibers, and that the application of penicillin in medicine would have been impossible except for 1he original, accidental discovery of penicillin by Alexander Fleming. The clearest example of the determinative part that is played by research in pure science is probably that of the controlled release of atomic energy. There has, of course, been a tendency to attribute to the physicists alone the development of atomic bombs and atomic power plants, but it is my feeling that chemistry should have a large part of the credit. For example, neptunium, the first of the transuranium elements to be discovered, was discovered by Edwin MacMillan and Dr. Abelson. Although Edwin MacMillan is professor of physics at the University of California, his first research was carried out in chemistry, under my direction, and $I$ have a strong feeling that his work along these lines has been strikingly effective because he possesses a sound knowledge of chemistry as well as of physics.

\section{Observation of Neto Natural Phenomena First}

Lei us consider the steps that were involved in the development of this new part of our civilization, the manufacture of atomic bombs and production of power from the atomic nucleus. First, there was the discovery of something really new, both the observation of new natural phenomena and the inspiration of new ideas. Becquerel observed that a rock (containing radium, as was found later) could fog a photographic plate through black paper. Einstein, just thinking about the nature of the physical world, saw with the inuer vision of his great intellect that a simplified pic:ture of the world could be formulated. and this picture led to the conclusion that matter and energy are interrelated: scientists then knew how great the amount of energy was that could be released by the destruction of matter. The positron was discovered by Carl Anderson, who wasn't looking for it. The neutron was discovered. The phenomenon of the fission of atomic nuclei was discovered. The transuranium elements were discovered. All of this foundation for the development of the atomic bomb and atomic power plants is a part of fundamental research-the search for unpredictable results, the effort to add to man's body of knowledge in any signitcant way. Becquerel could not lay plane to discover radioactivity-no one in the world had had imagination wild enough, bold enough, to predict or suspect that atoms could explode. Nobody, not evev Einstein himself, could plan to discover the theory of relativity. No bank would have lent money to Chadwick to subsidize his search for the neutron-20 years ago investment in atomic energy would have been called a preposterous idea by everybody. But it is these basic discoveries that determined the direction in which developmental research and subsequent practical application could be carried out.

Fundamental research is carried ont almost entirely in universities, by university professors, and to a smaller $\mathrm{rx}$ tent in private or governmental laboratories and, as a minor activity, in industrial laboratories. It is carried out by men and women whose temperment, ability, and training are such as to fit them for this unusual activity-that of looking for new knowledge without concern about its immediate use in the solution of practical problems--and the environment in universities seems to be especially well suited to this activity.

I believe that we all recognize that progress will cease unless new fundamental discoveries are made, and that the rate of progress is determined by the amount of fundamental research that is carried on. Two year's ago the President's Committee on Scientific Research emphasized the importance for the security and welfare of the nation of earrying on basic scientific research on an expanded scale. The recommendation was made that a national science foundation be established, and that federal funds amounting to $\$ 250$ million per year by 1957 be appropriated for the support of basic scientific research, mainly in, the universities of the nation.

Threc years ago, in delivering the first Remsen Memorial Lecture (1), the distinguished Chairman of the Board of Directors of our Society, Roger Adams, diacussed the importance of federal support of scientific research. He mentioned that there was controversy about the nature of the administration of the proposed science foundation-that the Kilgore Bill presented a plan for a politically controlled organization, and the Magnuson Bill proposed that the control and distribution of funds be left in the hands of the scientists. He mentioned the compromise bill that was under discussion. 
Even though the organization of the proposed national research foundation under the compromise bill resembles that which Hitler decreed for the Kaiser Wilhelm Gesellschaft after 26 years of extraordinarily successful operation by scientists, American scientists are supporting the bill as probably the best to be hoped for with our democratic government. They recognize that the necessity of a foundation in this country to support scientific research and the training of scientists is of utmost importance to the health, security, and welfare of the nation. They have faith that the present President of the United States or a succ'essor will not allow political influence to prejudice his appointments or decisions.

In Great Britain, the government allocutes a liberal amount of money for scientific research and development. These funds are administered by a small committee of distinguished scientists with full authority to distribute them to the best of their ability for the benefit of science and the British people.

In Rusia, all reports emanating from that country are to the effect that the government is supporting a very extensive progrim in fundamental research. But the fiussian seientists have their troubles. A few quotations from an address by P. I. Kapitza, the world-renowned Russian physicist and engineer. delivered hefore the Sovjet Academy of Sciences in 1943 on "The Institute of Plassics" of which he is the director, deserve repeating. He said. "The orGanizition of science in our country must he more systematic and conscious of its uims than it is in capitalistic countries where it is rather left to chance and has a spontaneous character." His institute had a complicated financial system which he strenuously opposed and which was finally changed. He stated, "In my debates with officials of the Commissariat of Finance on their so-called 'schematic system' of accounting, I wrote them the following: "When you look at a painling of Rembrandt, are you interested in the question of how much Rembrandt paid for his brushes and canvas? Why, when you consider a scientific job, do you want to know the cost of apparatus or the material used on it?' If a scientific job has produced considerable results, its value is not comparable with the material expenditure on it. The money cost of scientific work is not comparable with its cultural value. I asked, 'How much would the Peoples Commissariat for Finance have considered allotting to lsaac Newton for his work which led to the discovery of gravity?" The commissariat objected tirelessly. Our discussions went on for over six months and I think I could not have won unless the Council of Commissars had come to my aid." In commenting on these statements the director of another Russian institute remarked. "An everlasting war has to be waged with 'bookkeeping.'" It appears that the accounting systems required by the Russian and United States governments are not far different.

Progress in applied science depends upon advances in fundamental science. The power of science in the United States will be no more effective than the quality of our teachers and students who create the background for future industrial dis coveries. Once again I quote Kapitza who pleaded for recognition of fundamental science and its importance. "We, however, are often ant to judge scientific achievements only by their practical results and consequently it appears as if the person who picked the apple has done the main job, while in actual fact, the apple was created by the person who planted the tree."

The strength of a country has depended in the past on its possessions-in eillier days on land, its control of transportation and waterways, or its supply of raw materials, but today a nation's strength will lie largely in the quality of its scicnce and scientists. Government must support the work of scientists but not control it in such a way as to hamper development or to direct it into military channels. .

Now it is 1949. Three years have gone by since Dr. Adams delivered this Remsen address, four years since the national science foundation was strongly recommended to the President in the Bush Report, two years since the recommendation was repeated, still more strongly, in the Steelman Report--and there is still no national science foundation. Can we say that the members of the Congres: alone are to hlame for this situation? Are not we oursolves, the members of the Americax Chemical Society, also to be blamed? Should we not have done something more than to send a representative to a hearing of a Congressional committee, to send a letter or two written $\mathrm{by}$ the Board of Directors? I myself feel that we should have done something more, and that we should now do something more. in order to make clear to the urople of the nation that the scientists themselves believe the statements that they make about the importance of basic research.

\section{Should the ACS Take Part?}

The objection might be raised that it is not proper for the American ChemiCal Society to take part in political activities. I do not believe that this objection is a valid one. The purposes for which the American Chemical Societr exists are stated in the Act of Incorporation that constitutes its National Charter. Let me read Section 2 of the Charter:

Section 2. That the objects of the incorporation shall be to encourage in the broadest and most liberal manner the advancement of chemistry in all its branches; the promotion of research in chemical science and industry; the improvement of the qualifications and usefulness of chemists through high standards of professional ethics, education, and attainments; the increase and diffusion of chemical knowledge; and by its meetings, professional contacts. reports, papers, discussions, and publications, to promote scientific interest and inquiry, thereby fostering public welfare and education. aiding the development of our country's industries, and adding to the material prosperity and happiness of our people.

It seems to me that under this charter we have not only the right but the duty to educate the people of the nation, including the members of the Congress, about the questions that are discussed in the Bush Report and the Steelman
Report. The American Medical Assucittion, in some respects a sister organization to the American Chemical Societr, has made a far broader interpretation of its constitution than I advocate for our Society. Article 2 of the constitution of the American Medical Association reads as follows:

Article 2-Objects. The objects of the Association are to promote the science and art of medicine and the betterment of public health.

The association is now taking a vigorous part in the discussion of the federal compulsory health insurance plan proposed by Federal Security Administrator Oscar Ewing and endorsed by the President of the United States. President Truman in his message to the Congrese on Jan. 5 said "We must spare no effort to raise the general level of health in this country. In a nation as rich as ours it is a shocking fact that tens of millione lack adequate medical care. We are short of doctors, hospitals, and nurses We must remedy these shortages. Moreover, we need, and we must have withoul further delay, a system of prepaid medical insurance which will enable every American to afford good medical care." The American Medical Association's campaign against this proposal involves a program of public education to promote advancement of health under our present voluntary system. The program of public education is costing several million dollars, raised by assessments of $\$ 25$ per man on the membership of the AMA. Clem Whitaker, one of the two publicists who are the directors of the National Education Campaign of the American Medical Association, has described the purpose of the campaign in the following way: "American medicine, in its campaign against compulsory health insurance, can not afford to fight alone. This must be a campaign to arouse and alert the American people in every walk of life, until it generates a great public crusade and a fundamental fight for freedom. We need the help of every American who honestly believes in the American way of lifeand our campaign must be geared to get that help. Any other plan of action, in view of the drift toward socialism and despotism all over the world, would invite disaster."

In mentioning the American Medical Association and its national education campaign I hope that I do not give the impression that I myself am sympathetic to its aims. As an individual, I feel that a system of socialized medicine in the United States may well be desirable, and that at any rate it needs serious consideration. I find it difficult to understand why this nation, which pridea itself on being the richest nation in the world, should be inferior to Sweden and other small nations in the standards of 
health and medical care of its people. The American Medical Association in its releases nakes statements such as the following: "Considering our size, and races of people involved, we have made more progress than any nation on earth." I would be better satisfied if it were not necessary to qualify the statement. about our medical progress.

However, this is aside from the point What $I$ want to emphasize is that the American Medical Association is taking significant action on a question relating to federal legislation, and that there is. in my opinion, no reason why the AMERIcan Chemical. Society should not put on a strong program of public education about the overwhelming importance of federal support of scientific research, as advocated in the Bush Repnrt and the Steelman Report

\section{Dangers of Government Support}

It is true that there is danger in haviug basic scientific research in our universities supported exclusively or predomiantly by the Federal Government-thr danger of bureaucratic control of the universities and of scientific research In the absence of a national science foundation, the Public Health Service and the armed forces, especially the Department of the Navy, have been subsidizing pure research in our universities because of the recognition of the very great need of the nation for work in thifield. Many scientists, such as President DuBridge of the California Institute of Technology, have recognized the danger (D predominant support of research by the armed forces. A similar danger would of course apply to some extent to federal support through a national science foundation, amounting to $\$ 250$ million a year We recognize that there is this danger, and yet we see that the need to carry in basic research on the proposed scale exiats and must be met. What can be . Ione in this situation?

I feel that there is a way in which thr chreat of complete-domination of basic *ientific research by the Federal Govtrnment can be met, and I suggest that the American Chemical Socrety give *erious consideration to an active program of education along this line, as wel\} * for the national science foundation The way in which the people of the United States can avoid the danger of federal domination of research in the universities of the nation is by the provision of a comparable sum of money for support of research from other vources. I have in mind the formation if a foundation, like the Nutrition Foundation, which will collect funds from the (ndustrial corporations of our great nation and will distribute these funde mong our universities and pure research institutes. I suggest that, in order to be effective, this private enterprise fund for pure research be of considerable magnitude, amounting to $\$ 75$ million per year by 1957. I have reached the figure $\$ 75$ million per year by considering what sum would be effective as protection against the danger of federal subsidy of research in pure science of $\$ 250$ million per year and what sum would be reasonable in comparison with the sums expended by industry for developmental scientific research. A private enterprise research fund of $\$ 75$ million per year would be just $30 \%$ of the proposed federal subsidy; a smaller fraction could not be expected to have a significant effect in averting the dangers of bureaucratic domination The funds expended in research by industry in 1947 have been estimated at $\$ 450$ million, and the extrapolation in the Steelman Report indicates that this sum will be increased to $\$ 750$ million by 1957.

Accordingly my proposal is that a sum be provided by industry for research in pure science in our universities equal to $10 \%$ of that expended for developmental research. I believe that this fraction is reasonable, considering that the sum proposed for expenditure by the Federal Government in support of pure research in the universities would amount to $25 \%$ or more of the icderal budget for research in its own departments

\section{Insurance Not Charity}

We must not consider that suppert by the nation's industrial corporations of the proposed research foundation would rome under the heading of charity. Dr Bichowsky in his book on industrial research has stated that industrial research thould be considered by our corporations as insurance--insurance that the corporarions will have new products to manuiatcture in the future. In the same way. I would say that the proposed suppori of pure research should be considered as insurance, insurance that the research lepartments of the corporations will have basic knowledge that will permit them in the future, to exercise their nwn in+urance activities

I do not believe that the sun of $\mathbf{\$ 7 5}$ million per year is an unreasonable one. in comparison with either the profits of the gross income of the industrial corporations of the nation. The figure, $\$ 20$ billion, has been quoted as the anaual profits of our industrial corporarions. Seventy-five million dollars is only $0.375 \%$ of the profits-surely not a large fraction to pay for insurance. I do not know what the annual gross income of our industrial corporations is, but it must be of the order of $\mathbf{\$ 1 0 0}$ billion. Seventyfive million dollars is $0.075 \%$ of this sross annual income--surely a very small amount to expend to insure an improved product for the next generation.

In the distribution of the funds under the control of this research foundation
I would hope that the private institutions of the nation would be especially favored. The effects of the great increase in the cost of living-and the cost of carrying on research-during the past $1 \mathrm{~A}$ years have been in some degree alleviated in our state-supported universities by a great increase in the annual appropriations of the state legislatures The privately controlled and privately supported universities have, however, not had a corresponding increase in the eurnings from their endowments and in new gifts. There is in my opinion an especially erucial situation in our privato universities in that the size of the professorial staffs in chemistry and other sciences has not increased proportionately to the number of undergraduate and graduate students. Although the number of undergraduate students, as well as of graduate students in our universities has doubled in the last decade, the numtier of faculty members has increased by only about $25 \%$ on the average, and hy a smaller fraction in the privately iupported universities. At Harvard University there were 12 members of the themistry department in 1939 ; today this uumber has increased to 13 . In 1939 there were 14 members of the profts sorial staff of the division of chemistry and chemical engineering in the Caliiornia Institute of Technology, and now there are only 16, although the number of postdoctoral research fellows working in the division has increased during the lecalle from 16 to 40 and there has beev a corresponding increase in the number of graduate stadents. The expected consequences of such a deficiency in the professorial staffs are serious. The pruiessols, because of the overload of teaching, may not find it possible to keep even with the advance of scientific knowledge The students whom they train may come to the end of their period of traininy already somewhat behind the times; the universities would then be producing an unsatisfactorily trained group of men to "arry out scientifir work in the coming lecades

\section{Vo Restrictions}

This situation emphasizes the fact that in order to be effective, the funds dis tributed by the proposed research foundation should be given to the universities essentially without restrictions as to the way in which the money will be expended, and the research foundation should be set $u p$ in such a way that there is assurance that the funds will continue to be available year after year.

Let me support my thesis by quoting from an editorial by Walter J. Murphy in Chemical and Enoinefring Newe (2). "One obvious answer is to turn more and more to Government, and there are many advocates of such a plan. But a great many more citizens of this 
country are not in favor of complete bureaucratic federal control of our institutions of higher learning. Only a mere handful, however, sense the pressing necessity of doing something tangible to offset the drift toward Washington control financed by the tax powers of the Government.

"Corporations have done a great deal. Today thousauds of scholarships and fellowships ure provided for through funds made available by corporations, both large and small. In this regard the record of the chemical industry and industries allied to it is an outstanding one But much more must be done before we can say truthfully that what is being accomplished is a corrective measure and will offset the efforts of those who would make higher education in this country the full responsibility of the Federal Government. Perhaps it is inevitable likat Government must share the burden, but private enterprise must not shun its responsibilities and must not abdicate in favor of complete government control. If industry does its part and publicizes such action properly, the American public will be aware that corporations are not soulless affairs seeking only to make profits, unmindful of their public duties.

"We have in industry and in the large corporations of this country the best brains and the best organizing abilities the world has ever seen. Is it not time that some of these individuals came forth to undertake the task of assisting on a nationwide basis, our institutions of higher learning? If the present tax laws are inimicable to the success of such a program, then let them first establish a campaign of education. The job is a difficult one and certainly an unenviable assignment, but the results obtained by industrial leaders under the stress of war is indicative of what they are capable of doing under any set of circumstances once the need is made evident. Here is onc of the greatest challenges of our time. It is a pity it is understood by so few."

I have now presented my thesis. I have repeated the arguments, already well known to you, showing that for the national welfare it is essential that there be extensive support of fundamental scientific research by the Federal Government. I have repeated the arguments about the dangers of bureaucratic domination. I hope that the members of the boards of directors of our industrial corporations, in justice to our American system of private enterprise, will see that they have the opportunity to help to avert the danger that they foresee by themselves providing a more significant part of the support of pure research in our universities and research institutes. I believe that we, as individuals, and the American Chemical Societr, as an organization, have the duty to work vigorously both for a national science foundation to implement the recommendations in the Bush Report and the Steelman Report and for a great research foundation subsidized by our industrial corporations.

\section{Literature Cited \\ (1) Chems. And ENg. News, 24, 1643 (1946). \\ (2) Ibid., 26, 2345 (1948).}

The Cover ....

\section{Moduliffe Named to Succeed Waitt}

Mas. Gen. Anthony c. McAuliffe, former Deputy Director of the Arrny General Staff's Research and Development Board, has been nominated by President Truman to head the Army Chemical Corps. Following confirmation by the Senate, Gen. McAuliffe will lake over his duties, replacing $\mathrm{Maj}$. Gev Alden H. Waitt, whose application for retirement has been approved.

After characterizing himself as an "old crock" too old to be engaged in active exploits. 51-year-old, slightly built "Old Crock" McAuliffe parachuted into Normandy on D-Day to help open the road for the troops storming the beach.

"Tony" McAuliffe was born in Washington, D. C., on July 2, 1898 . His military career began in November, 1918, when he was commissioned as a second lieutenant on his graduation from the U.S. Military Academy, West Point, N. Y. He became a national figure in 1944 when he gave his classic response of "Nuts!" to a German demand that he surrender his surrounded troops during the Battle of the Bulge. During this battle his radio operator likened the position of the American troops to the "hole in the doughnut."

Gen. MeAuliffe's thirty-odd year military career has been spent primarily in the Field Artillery Service. In addition, his experience has included assignment in Hawaii as assistant to the plans and training officer, and he was associated with the supply division of the War Department general staff, as well as the Army Service Forces, Washington, D. C. During World War II he participated in the airborne attacks in France on D-Day and later in Holland. He was active in the invasion of Germany. In January, 1946, he became Ground Forces Adviser to Vice Admiral W. H. P. Blandy, Commander of the Joint Army-Navy Task Force One for Operation Crossroads, the test of the atomic bomb. He served at Bikini throughout the tests, helping to assess the effects of the bomb explosions. He returned to Washington in August, 1946, to become Army Secretary of the Joint Researcb and Development Board.

In December 1947 he was designated Deputy Director for Research and Development, Logistics Division, General Staff, U. S. Army. In this position, he had an opportunity to becoms familiar with such important aspects of national defense as bacteriological warfare. He held this position until his recent appointment as Commanding General of the 24th Infantry Division in Japan.

Former associates have stated that as a result of his work at the Research and Development Board, Gen. McAuliffe is familiar not only with the work of the Chemical Corps, but also with the over. all program of the Army's various technical services. Fie is a strong believer in the need and value of military research and development and favors a balanced program with respect to eivilian and military scientists. He also advocates close cooperation between the military services and the various technical societies. Although conservative in his views and a middle-of-theroader with respect to innovations, he has an open mind and when convinced of the merits of an idea is active in putting it into operation. Gen. McAuliffe supported preparation of a critical analysis of the weaknesses in effectively utilizing scientific manpower during World War II (see Potomac Postscripts, Jan. 24, 1949).

Reliable sources stated that complications arising as a result of the recent Senate investigation in which Gen Waitt's name was involved made it impossible to nominate a candidate from within the Chemical Corps. Therefore, \& well-respected man experienced in research and development aspects of the army program. such as Gen. MeAuliffe, was selected.

Among his numerous U. S. and foreign decorations, Gen. MeAuliffe holds the Distinguished Service Cross and two Presidential citations. He has held a temporary rank of major general since January, 1945, and a permanent rank of brigadier general since June, 1944

Gen. McAuliffe is married and has a son, John, a former army officer, and a daughter, Patricia, who is now in Japan with her parents. 